$$
\begin{aligned}
& \text { قسم الانتاج الحيوانى }
\end{aligned}
$$

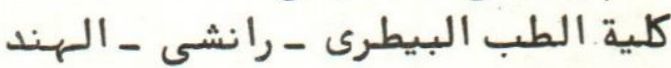

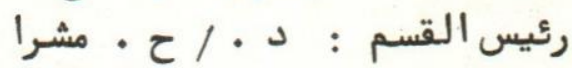

د راسة من العـوامل التى تؤ ثر ملى مدة الشبق فـــــ

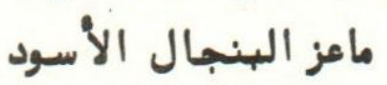

$$
\text { د سنج ، ر• سنج ، س. سنج ، • مشبـرا ، م سنج }
$$

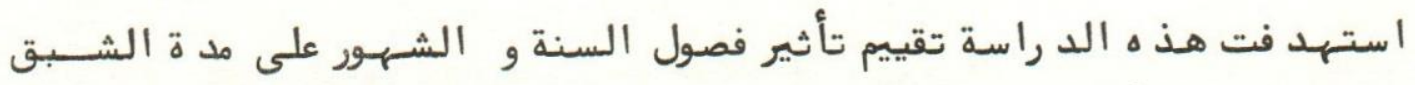

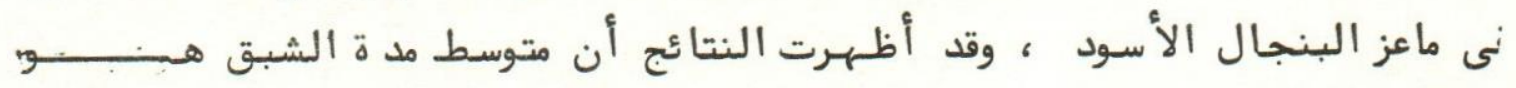

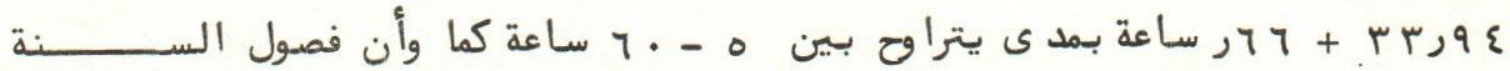

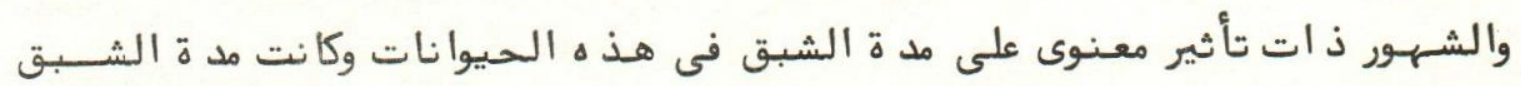

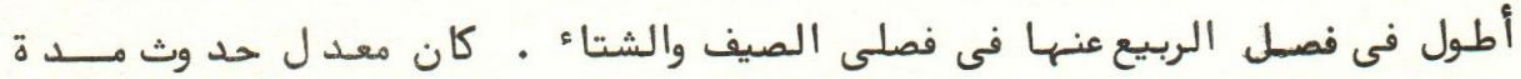

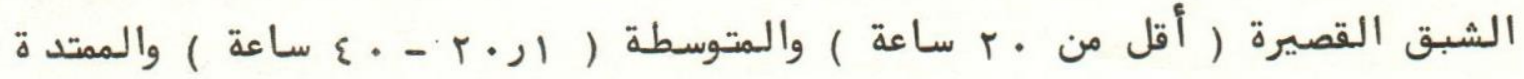

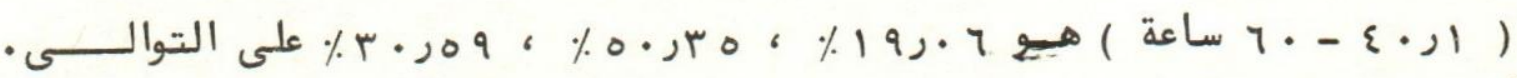

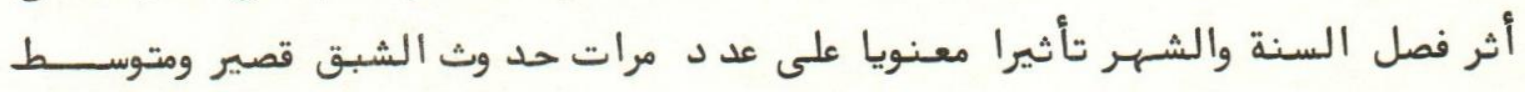
وممتد المدة . 

Dept. of Animal Breeding \& Genetics,

Faculty of Vet. College, Ranchi, India.

Head of Dept. Dr. H.R. Mishra.

\title{
STUDIES ON FACTORS AFFECTING DURATION OF OESTRUS IN BLACK BENGAL GOATS \\ (With 4 Tables)
}

\author{
By
D.K. SINGH; R.A. SINGH; C.S.P. SINGH; H.R. MISHAR \\ and M.P. SINGH \\ (Received at 27/12/1984)
}

\begin{abstract}
SUMMARY
425 oestruses exhibited by 178 Black Bengal goats of different parities (Nulliparous, Primiparous \& Pluriparous) during three seasons viz: winter (November-February), summer (March-June) and monsoon (July-October) were analysed to study th effect of parity, season, month and interaction of parity with season and month. The overall duration of oestrus was $33.94+0.66 \mathrm{~h}$. ranging between 5 to $60 \mathrm{~h}$. The effect of month, season and interactions of parity with month and season were significant on duration of oestrus in these goats. Duration of oestrus during monsoon was significantly more $(36.21+0.98 \mathrm{~h})$ than that of winter $(31.78+1.08$ h) and summer $(31.84+1.40 \mathrm{~h})$ which did not differ significantly among them-selves. The overall incidence of short (/ $20 \mathrm{~h})$, medium (20.1-40.0 h) and prolonged oestrus (40.1-60.0 h) was 19.06, 50.35 and $30.95 \%$ respectively. The effect of season and parity was significant on the incidence of short, medium and prolonged oestrus.
\end{abstract}

\section{INTRODUCTION}

To provide a sound basis for successful artificial insemination/natural mating in goats, it is essential to study the duration of oestrus and faetors influencing it. Only a few reports are available on duration of oestrus in Black Bengal goats.

The present study was therefore conducted to estimate the influence of various factors viz: parity, month, season and interactions of the duration of oestrus. Attempts were also made to study the incidence of short, medium and prolonged oestrus in the goats of different parities during three seasons.

\section{MATERIAL and METHODS}

A total of 178 Black Bengal females of different parities (Nulliparous, Primiparous and Pluriparous) exhibiting 425 oestruses during three seasons viz: winter (November-February); summer (MarchJune) and monsoon (July-October) during 1982-83 were included in this study. The oestrus was detected by vasectimized bucks at every 4 hours throughout the period. Time of onset and cessation was recorded as the time of first and last mounting of vasectomized buck on oestrus goats. Feeding and managemental conditions were similar during the period of study. The duration of oestrus was classified into three classes viz: short (/ $20 \mathrm{~h})$; medium (20.1-40.0 h) and prolonged 40.1-60.0 h) to study the incidence of different classes of oestrus exhibited by the goats of different parities during the seasons under study.

Assiut Vet.Med.J. Vol. 15, No. 29, 1985. 
The data were analysed statistically to evaluate the effect of parity, seeson; month and interactions of parity with season and month by using following linear statistical model (SNEDECOR and COCHRAN, 1968).

$Y_{i j k l}=u+a_{i}+b_{j}+c_{k}+(a b){ }_{i j}+(a c)_{j k}+e_{i j k l m}$ where, $Y_{i j k l m}$ is the $m$ th observation of 1 th goat in ith parity, $j$ th season and of $k$ th month

$u$ is the overall mean

$a_{i}$ is the effect of $k$ parity

$b_{j}$ is the effect of $j^{\text {th }}$ season

$c_{k}$ is the effect of $k^{\text {th }}$ month

$(\stackrel{k}{a b})_{i j}$ is the ineraction effect between parity and season

(ac) ${ }_{\mathrm{ik}}$ is the interaction effect between parity and month

$\mathbf{e}_{i j k l m}$ is the error term NID $\left(0,5^{2} e\right)$

The differences in frequencies of goats showing short, medium and prolonged oestrus during fifferent parities and seasons were tested by Normal-Deviate test (SNEDECOR and COCHRAN, 1968).

\section{RESULTS}

Average values of duration of oestrus have been shown in Table 1.

Table (1):

Analysis of variance to evaluate the effect of parity, season, month and interactions of parity with season and month was calculated and presented in Table (2).

\section{Table (2):}

The overall duration of oestrus was $33.94+0.66 \mathrm{~h}$ (Table 1). The effects of season, month and interactions of parity with season and month on average duration of oestrus were significant (Table 2). The duration of oestrus was significantly longer during monsoon season $(36.21+0.98 \mathrm{~h}$ ) than that of winter and summer $(31.78 \pm 1.08$ and $31.84+1.40 \mathrm{~h}$ respectively). The differences between parities was not significant but the primiparous goats exhibit longer duration of oestrus $(35.10+2.12$ h) than that of nulliparous $(33.83 \pm 1.45 \mathrm{~h})$ and pluriparous $(33.75+0.78 \mathrm{~h})$. With respect to the effect of months, the duration of oestrus ranged between $39.18 \pm 2.02 \mathrm{~h}$ (October) and $21.50 \pm 3.50 \mathrm{~h}$ (April). The frequency of occurance of oestrus during march was zero.

Frequencies of short, medium and prolonged oestrus have been presented in Table 3.

\section{Table (3):}

The overall frequencies of short, medium and prolonged oestruses were 19.06, 50.35 and 30.59 percent respectively. In nulliparous, primiparous and pluriparous goats the frequencies of short, medium and prolonged oestruses were 23.33, 48.89 and $27.78,23.21,33.93$ and 40.62, 16.85, 54.12 and 29.03 percent respectively.

The difference in frequencies between parities and seasons were tested by Normal-Deviate test and presented in Table 4.

The effect of parity and season on the frequencies of short, medium and prolonged oestruses were significant (Table 4). 


\section{DURATION OF OESTRUS IN GOATS}

\section{DISCUSSION}

One of the important factors for significantly longer duration of oestrus in goats during monsoon was increased nutrition in the form of availability of abundant green grasses. Another factor contributing it was probabiy a higher concentration of sex hormencs in the herbage as reported by ROY et al. (1962). Start of winter probably had a stimulating effect on the duration of oestrus in goats as was evident from the longest during October (Table 1). Month of October seemed to have very favourable influence on reproductive system of she goats of this area are not only in the form of longer oestrus but also having highest incidence of oestrus (MISHRA and BISWAS, 1966 and SINGH et al. 1978). Start of summer on the other hand had a diminishing influence on the reproductive system of she goats as evidenced by the shorter oestrus during February and April (being absent during March). SINGH et al. (1978) also observed that the incidence of oestrus was lowest during March. Effect of parity was not significant on duration of oestrus.

The overall frequencies of short, medium and prolonged oestrus were 19.06, 50.35 and 30.59 percent respectively, (Table 3). CARMENALE (1977) reported that the duration of oestrus averaged less than $24 \mathrm{~h}$ in 16 and $17 \%$ females; $24-36 \mathrm{~h}$ in 66 and $64 \%$; $37-48 \mathrm{~h}$ in 17 and $14 \%$ and $48 \mathrm{~h}$ in 1 and $4 \%$ in Saanen and Toggenburg goats respectively.

A careful observation of the influence of season on the trend of duration of oestrus revealed that in winter there was a gradual decrease in the incidence of short oestrus with the increase in parity. During monsoon, there was an increase in the frequency of short oestrus from nullipara to primipara which declined in the pluripara. The frequency of medium oestrus decreased during winter, summer and monsoon from nulliparous to primiparous, to show an increase in pluriparous. In all the three seasons the frequency of prolonged oestrus increased from nullipara to primipara and then declined in pluripara.

\section{REFERENCES}

Carmenale, C. (1977): A study of some reproductive prameters in Saanen and Toggenburg goats. Anim. Breed. Abstr., 47, 460.

Mishra, H.R. and Biswas, S.C. (1966): A study on the distribution of oestrus in desi goats. Indian J. Dairy Sci., 19, 132-34.

Roy, A.; Dutta, I.C.; Sahni, K.L.; Singh, B. and Sengupta, B.P. (1962): Studies on certain aspects of sheep and goat husbandry. Artificial breeding, telescoping and breeding season and certain reproductive phenomena in sheep and goat. Indian J. Vet. Sci., 32, 269-75.

Singh, C.S.P.; Shrivastava, B.N. and Singh, S.K. (1978): A note on the incidence of oestrus in goats. Indian J. Anim. Sci., 48, 67-70.

Snedecor, G.W. and Cochran, W.G. (1968): Statistical Methods, 6th edn. lowas State Univ. Pres, Ames. USA. 
D.K. SINGH, et al.

Table 1: Average values of duration of oestrus (hours)

\begin{tabular}{|c|c|c|c|}
\hline Groups & $\begin{array}{l}\text { No. of } \\
\text { observation }\end{array}$ & Mean values & $\begin{array}{l}\text { C.D. values } \\
\text { at } 5 \%\end{array}$ \\
\hline Overall & 425 & $33.94 \pm 0.66$ & \\
\hline \multicolumn{4}{|l|}{ Parities: } \\
\hline Nullidarous $\left(P_{1}\right)$ & 90 & $33.83 \pm 1.45$ & \\
\hline Primidarous $\left(\mathrm{P}_{2}\right)$ & 56 & $35.10 \pm 2.12$ & \\
\hline Pluriparous $\left(\mathrm{P}_{3}\right)$ & 279 & $33.75 \pm 0.78$ & \\
\hline \multicolumn{3}{|l|}{ Seasons: } & \multirow[t]{4}{*}{3.16} \\
\hline Winter $\left(\mathbf{s}_{1}\right)$ & 125 & $31.78 \pm 1.08^{a}$ & \\
\hline Summer $\left(\mathrm{S}_{2}\right)$ & 94 & $31.84 \pm 1.40^{\mathrm{a}}$ & \\
\hline Monsoon $\left(s_{3}\right)$ & 206 & $36.21 \pm 0.98^{b}$ & \\
\hline \multicolumn{3}{|l|}{ Months: } & \multirow[t]{12}{*}{12.89} \\
\hline January & 13 & $31.88 \pm 3.52^{a b c}$ & \\
\hline February & 3 & $24.67 \pm 2.91^{\mathrm{ab}}$ & \\
\hline ADr11 & 2 & $21.50 \pm 3.50^{\circ}$ & \\
\hline May & 13 & $32.84 \pm 4.17^{a b c}$ & \\
\hline June & 79 & $31.94 \pm 1.52^{\mathrm{abc}}$ & \\
\hline July & 3 & $32.33 \pm 8.35^{a b c}$ & \\
\hline August & 30 & $33.63 \pm 2.31^{\mathrm{abc}}$ & \\
\hline September & 124 & $35.76 \pm 1.67^{b c}$ & \\
\hline October & 49 & $39.18 \pm 2.02^{c}$ & \\
\hline November & 57 & $31.96 \pm 3.07^{\mathrm{abc}}$ & \\
\hline December & 52 & $31.97 \pm 1.52^{\mathrm{abc}}$ & \\
\hline \multicolumn{3}{|l|}{ Parity x Seasons: } & \multirow[t]{10}{*}{7.04} \\
\hline$P_{1} s_{1}$ & 21 & $23.30 \pm 1.61^{\mathrm{a}}$ & \\
\hline$P_{1} S_{2}$ & 21 & $35.61 \pm 2.92^{\mathrm{bcd}}$ & \\
\hline $\mathrm{P}_{1} \mathrm{~S}_{3}$ & 48 & $37.67 \pm 2.02^{\mathrm{cd}}$ & \\
\hline$P_{2} S_{1}$ & 12 & $30.83 \pm 4.16^{b c}$ & \\
\hline $\mathrm{P}_{2} \mathrm{~S}_{2}$ & 12 & $38.65 \pm 4.81^{\mathrm{d}}$ & \\
\hline $\mathrm{P}_{2} \mathrm{~S}_{3}$ & 32 & $35.36 \pm 2.87^{\mathrm{bcd}}$ & \\
\hline$P_{3} s_{1}$ & 92 & $33.84 \pm 1.24 \mathrm{bcd}$ & \\
\hline $\mathrm{P}_{3} \mathrm{~S}_{2}$ & 61 & $29.21 \pm 1.59^{\mathrm{ab}}$ & \\
\hline$P_{3} S_{3}$ & 126 & $35.87 \pm 1.21^{\mathrm{bcd}}$ & \\
\hline
\end{tabular}

Mean values bearing same suberscripts for seasons, months, and parity $x$ season did not differ significantly. 
Table 2: Analysis of variance showing the effect of parity. season, month on duration of oestrus

\begin{tabular}{l|rc|l}
\hline $\begin{array}{l}\text { Source of } \\
\text { variation }\end{array}$ & d.f. & Mean squares (MS) & $F$ \\
\hline Between parities & 2 & 43.1125 & 0.2594 \\
Between months & 10 & 314.2551 & $1.8912^{*}$ \\
Between seasons & 2 & 1029.2712 & $6.1942^{\text {** }}$ \\
Parity x season & 4 & 811.2668 & $4.8822^{\text {** }}$ \\
Parity x month & 20 & 267.6349 & $1.6106^{*}$ \\
Error & 386 & 166.1670 & \\
\hline
\end{tabular}

$* P \angle 0.05 ; * ; P \angle 0.01$.

Table 3a Frequencies $(x)$ of short, medium and prolonged oestrus in goats

\begin{tabular}{|c|c|c|c|c|c|c|c|c|c|c|c|c|c|}
\hline \multirow{2}{*}{$\begin{array}{l}\text { Type of } \\
\text { oestrus } \\
\end{array}$} & \multicolumn{12}{|c|}{ PARITIFS } & \multirow{2}{*}{ Overall } \\
\hline & $\frac{\mathrm{Nu}}{\text { Winter }}$ & $\begin{array}{l}\text { I11paro } \\
\text { Summer }\end{array}$ & Monsoon & Total & Winter & $\begin{array}{l}\text { Primit } \\
\text { Summer }\end{array}$ & Arous & Protal & $\begin{array}{r}\text { P } \\
\text { Winter }\end{array}$ & $\begin{array}{l}\text { Iuridare } \\
\text { Summer }\end{array}$ & Dus & n potal & \\
\hline $\begin{array}{l}\text { Short } \\
(\angle 20 \mathrm{hrs})\end{array}$ & 61.90 & 4.76 & 14.58 & 23.33 & 33.33 & 16.67 & 21.88 & 23.21 & 14.13 & 27.87 & 13.89 & 16.85 & 19.06 \\
\hline $\begin{array}{l}\text { Medium } \\
(20.1-40.0 \mathrm{hrs})\end{array}$ & 38.10 & 52.38 & 52.08 & 48.89 & 33.33 & 25.00 & 37.50 & 33.93 & 61.96 & 50.82 & 50.00 & 54.12 & 50.35 \\
\hline $\begin{array}{l}\text { Prolonged } \\
(40.1-60.0 \mathrm{hrs})\end{array}$ & 0.00 & 42.86 & 33.34 & 27.78 & 33.33 & 58.33 & 40.62 & 42.86 & 23.91 & 21.31 & 36.51 & 29.03 & 30.59 \\
\hline
\end{tabular}

Assiut Vet.Med.1. Vol. 15, No. 29, 1985. 
D.K. SINGH, et al.

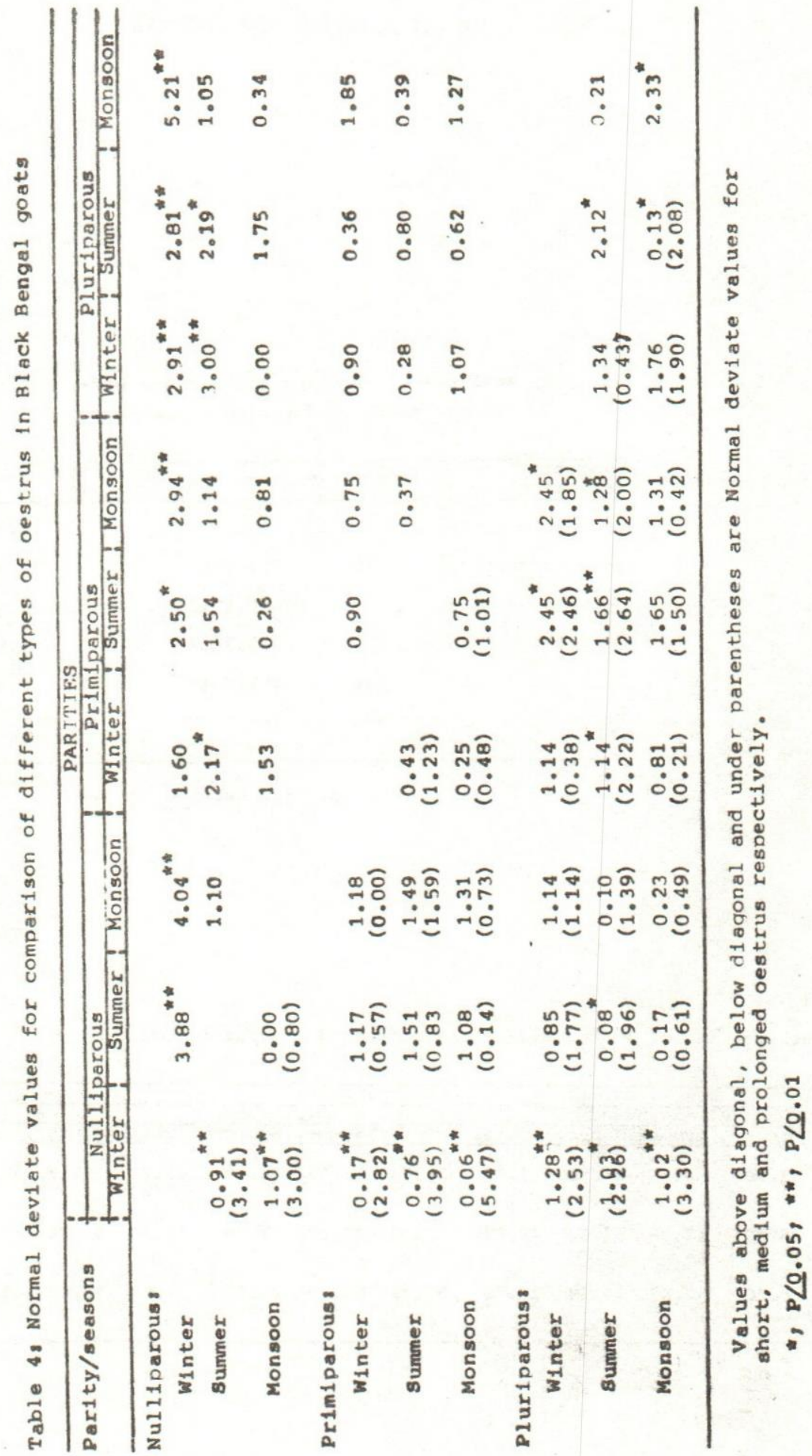

